DOI: https://doi.org/10.24144/2409-6857.2020.1(55).49-53

УДК 338.482

\author{
Стручок Н.М., Замрій О.М.
}

\title{
УПРАВЛІННЯ ТУРИСТИЧНИМ БІЗНЕСОМ В ГЛОБАЛЬНОМУ ПРОСТОРІ
}

\begin{abstract}
У статті визначено місце туристичного бізнесу у глобальному економічному просторі. Проаналізовано економічний ефект від розвитку ринку туристичних послуг. Окреслено темпи зростання обсягів міжнародного туризму в туристичних регіонах світу. Досліджено теоретичні засади розвитку моделей управління туристичним бізнесом в глобальному просторі, визначено переваги та недоліки кожної з моделей. Визначено організачійну структуру управління туристичним бізнесом в Украӥні. Опираючись на досвід Канади, визначено як потужний інструмент розвитку туризму через залучення місиевих підприємств у різноманітні кластери, інформачійно-аналітичну підтримку, нормативно-правову підтримку, податкові пільги.
\end{abstract}

Ключові слова: туристичний бізнес, глобальний простір, міжнародний туризм, моделі управління туристичним бізнесом, організаційна структура управління туристичним бізнесом.

Постановка проблеми. Глобальна економіка розширяє просторові та часові параметри діяльності туристичного бізнесу як реального сектора національної економіки за рахунок створення нових туристичних продуктів. В умовах глобального розвитку туризм набув статусу феномена XXI століття. I це недивно, враховуючи підвищення ролі сфери послуг, порівняно 3 виробничою, в економічному розвитку країн. Глобальна інформатизація, що активно впроваджується в усі сфери економіки та притаманна для останніх десятиліть, сприяла розширенню сегментів ринку туристичних послуг i посиленню впливу туристичного бізнесу на макроекономічні показники національних економік. Провідні науковці визнали інформатизацію складником процесу глобалізації, а проблему розвитку i наслідків упровадження інформаційних технологій безпосередньо пов'язують із техноглобалізмом i теоріями інноваційного розвитку світової економіки

Важлива роль міжнародного туризму в розвитку країн пояснюється одночасним розумінням його як культурного явища, так і економічного, який $є$ формою міжнародних економічних відносин i функціонує відповідно до економічних теорій світогосподарських зв'язків. Незважаючи глобальне сповільнення темпів економічного

(с) Стручок Н.М. к.е.н, доц., завідувач кафедри міжнародної економіки та інвестиційної діяльності Львівського інституту економіки і туризму, м. Львів, Україна

Замрій О.М. старший викладач кафедри менеджменту та комерційної діяльності Львівського інституту економіки i туризму, м. Львів, Україна росту, диверсифікації кризових явищ, у тому числі зростання частки терористичних актів, цьогорічної кризи біженців унаслідок політичновійськових конфліктів, сучасна індустрія туризму залишається однією 3 найдинамічніших темпів зростання галузей світового господарства. Аргументом на користь зазначеної тези може бути й те, що вперше за останні роки темпи зростання туризму перевищили темпи зростання інших галузей світової економіки.

Аналіз останніх досліджень і публікацій. У наукових дослідженнях вітчизняних та міжнародних вчених окреслено ключові засади організації управління туристичною галуззю, зокрема знайшли свою відображення зазначені постулати у постулатах Козачковської Г.В., Кіркової Н.П., Хорош В.В., Мальської М.В., Дубової А.В., Свиридової Н.Д., Рутинського М.Й., Дидечко Л.П. тощо. Проте питання розвитку туристичної галуззі країни та піi інтеграція у глобальний економічний простір потребує глибшого та багатоаспектного аналізу.

Формування цілей статті. Метою нашого дослідження $є$ вивчення механізмів управління туристичним бізнесом в глобальному економічному просторі та пошук оптимальних векторів розвитку для України.

Опис основного матеріалу дослідження. У багатьох країнах туризм входить у першу трійку провідних галузей держави, розвивається швидкими темпами і відіграє важливе соціальне та економічне значення, оскільки він:

- збільшує місцеві доходи;

- створює нові робочі місця;

- розвиває всі галузі, пов'язані з виробництвом туристичних послуг;

- розвиває соціальну та виробничу інфраструктури у туристичних центрах; 
- активізує діяльність народних промислів і розвиток культури та сприяе їм;

- забезпечує зростання рівня життя місцевого населення;

-збільшує валютні надходження[1].

Основними критеріями виміру міжнародного туризму $є$ обсяги туристичних прибутуттів та прибуток, що отримує країна від міжнародного туризму. На рисунку 1 зображено динаміка доходів від міжнародного туризму на світовому рівні. Так у 2011 році темп зростання обсягу прибутку від міжнародного туризму становив $11 \%$, а у 2015 році $3,6 \%$, у 2018 році при порівнянні до 2017 році 7,8\%, що свідчить про тенденцію збільшення витрат кожного туриста під час подорожі у країни світу.

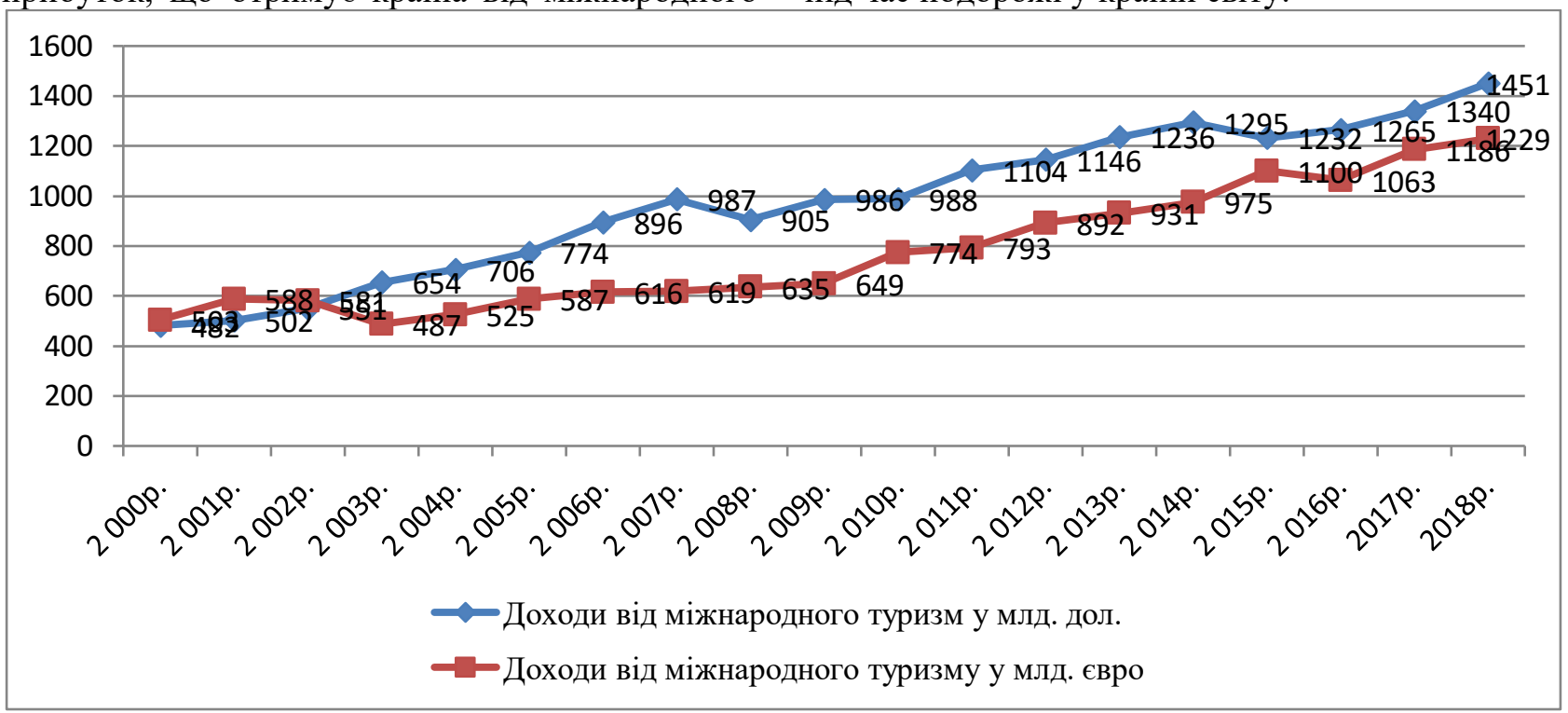

Рис.1. Динаміка зміни доходу на міжнародного ринку туристичних послуг протягом 2000-2018pp [2,3,4]

У цілому доходи від міжнародного туризму зросли у всіх регіонах світу. За даними ВТО у 2016 році найвищий прибуток від міжнародного туризму отримав Свропейський регіон - 615 млд.доларів,
Азіатсько-Тихоокеанський 309 млд.дол, Американський 200 млд.дол., Африканський 58 млд.дол., Близький Схід отримав 54 млд.дол. (рис.2.).
Американськи й регіон; 333,6

\section{Африканський} регіон; 38,4

\section{Близький Схід ; 73}

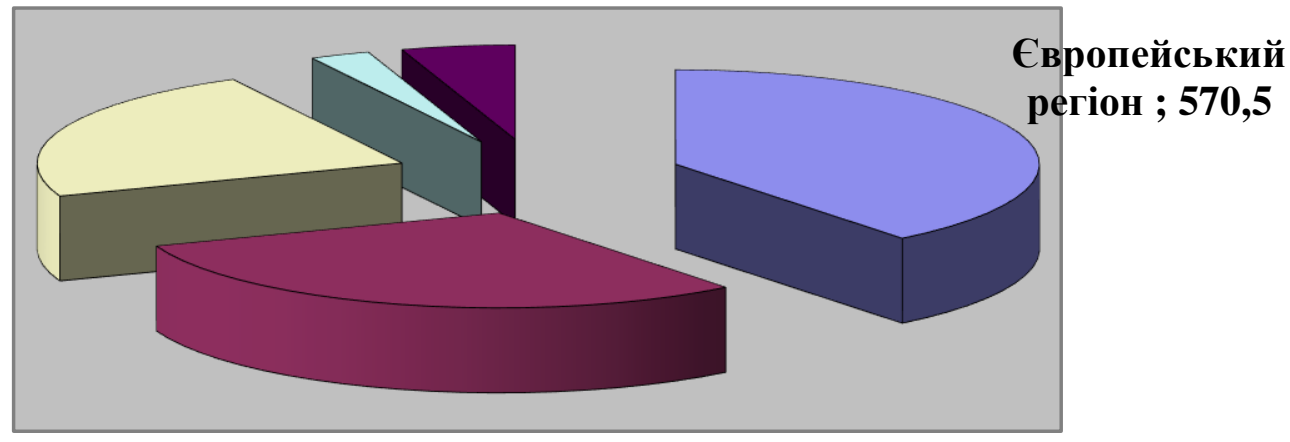

Азіатсько-

Тихоокеанськи

й регіон; 435,5

Рис.2. Доходи від міжнародного туризму у регіонах, 2018 рік, млд.дол. [2,3,4] 
Аналізуючи обсяги міжнародного туризму в регіонах за останні вісім років, можна відзначити позитивну динаміку, незважаючи на об’єктивні коливання в деяких періодах ( табл 1).

Таблиця 1

Темпи зростання обсягів міжнародного туризму в туристичних регіонах, \%*

\begin{tabular}{|c|c|c|c|c|c|c|}
\hline \multirow[t]{2}{*}{ Роки } & \multirow{2}{*}{$\begin{array}{c}\text { Світовий } \\
\text { туристичний } \\
\text { ринок у } \\
\text { цілому }\end{array}$} & \multicolumn{5}{|c|}{ Туристичні регіони світу } \\
\hline & & Свропейський & $\begin{array}{l}\text { Африкан- } \\
\text { ський }\end{array}$ & $\begin{array}{c}\text { Близькосхід- } \\
\text { ний }\end{array}$ & $\begin{array}{c}\text { Азіатсько- } \\
\text { Тихоокеан- } \\
\text { ський }\end{array}$ & $\begin{array}{l}\text { Американ- } \\
\text { ський }\end{array}$ \\
\hline 2008 & 1,9 & 0,3 & 4 & 18 & 1 & 3 \\
\hline 2009 & $-3,9$ & -6 & 3 & -5 & -2 & -5 \\
\hline 2010 & 6,5 & 3 & 7 & 14 & 13 & 6 \\
\hline 2011 & 4,6 & 6 & 1 & -8 & 6 & 4 \\
\hline 2012 & 4,7 & 2,0 & 6 & -2 & 6 & 6 \\
\hline 2013 & 4,6 & 5,0 & 5 & 0 & 6 & 3 \\
\hline 2014 & 4,2 & 3,0 & 2 & 5 & 5 & 8 \\
\hline 2015 & 4,6 & 5,0 & 3 & 2,0 & 5 & 5 \\
\hline 2016 & 3,9 & 2,8 & 5,1 & $-2,4$ & 7,7 & 3,7 \\
\hline 2017 & 7,0 & 7,4 & 7,3 & 1,5 & 7,4 & 7,4 \\
\hline 2018 & 5,4 & 5,6 & 7,1 & 10,2 & 5,2 & 3,2 \\
\hline
\end{tabular}

*- побудовано на основі $[2,3,4]$

Таким чином, як видно 3 табл. 1, за останній період часу середні темпи зростання обсягів міжнародних туристичних відвідувань були на рівні $2,5-5 \%$ в кожному із регіонів. Динамічний характер розвитку туризму в Близькосхідному регіоні пов'язаний, в першу чергу, 3 впливом соціальних та політичних факторів.

У Державній програмі розвитку туризму на $2002-2010$ рр. одним 3 нагальних завдань визначено забезпечення удосконалення структури управління у туристичній галузі на державному та регіональному рівнях, координації дій центральних i місцевих органів виконавчої влади з цього питання [5].

У глобальному е економічному просторі розвиток туристичної галузі базується на трьох моделях управління [6].

Перша модель грунтується на засадах децентралізованого управління. Ї̈ї особливість полягає у відсутності центрального державного органу (туристичної адміністрації), який б відповідав за розвиток туристичної галузі. Всі питання розвитку туризму вирішують на місцях на положеннях ринкової самоорганізації. Уряди окремих країн використовують таку модель у тому разі, якщо туризм країні взагалі непотрібний або коли суб'єкти туристичного ринку $\epsilon$ свідомими та займають сильні позиції, тобто здатні розв'язувати власні проблеми без участі держави. Саме таку модель управління туризмом нині застосовують у США, де в 1997 р. була ліквідована державна структура USTTA (United States Tourist and Travel Authority, Туристична адміністрація США), що керувала туризмом раніше. Керівництво США пояснило таке рішення низкою причин, серед них - зменшення витрат федерального бюджету, міцні позиції США на міжнародному туристичному ринку, привабливість країни для іноземних туристів, сильні приватні компанії в туристичному бізнесі США, здатні на потужні самостійні рекламні акції в інтересах всього національного ринку.

Друга модель - централізоване державне управління туризмом - передбачає наявність сильного й авторитетного міністерства туризму, яка контролює діяльність туристичної галузі загалом. Для реалізації цієї моделі потрібні певні умови: великі державні фінансові вкладання в туристичну індустрію, рекламно-маркетингову діяльність, a також потужне державне інвестування в інфраструктуру. Прикладами країн, де застосовують таку модель, $є$ Туреччина, Єгипет, Туніс, Таїланд, Індонезія, Кенія та деякі інші країни, в яких туризм - одне 3 головних джерел валютних надходжень. 
Третя модель управління туризмом (iі можна назвати європейською) переважає в європейських країнах і полягає в тому, що питання розвитку туристичної діяльності країни вирішується на рівні певного багатогалузевого міністерства.

При цьому департамент, який займається туризмом, має два основні напрями діяльності:

1) пов'язаний із глобальними питаннями державного регулювання туристичної галузі (зокрема, розробка нормативно-правової бази, координація діяльності регіонів, міжнародне співробітництво на міждержавному рівні, обробка статистичної інформації); 2

2) стосується маркетинго-виставкової діяльності (у тому числі управління туристичними представництвами за кордоном).

Розглянемо цю модель детальніше, адже вона найбільш сприятлива для України. Державні туристичні адміністрації в європейських країнах працюють шляхом взаємодії з місцевою владою та приватним бізнесом 3 метою заохочення до виконання державних завдань за допомогою фінансових засобів 3 приватного сектору, знаходження взаємовигідних форм співробітництва між органами управління різних регіонів. Унаслідок такої політики виникають змішані за формами власності (державноприватні) структури 3 регулювання туристичної діяльності.

Механізм управління розвитку туристичної галузі формують державні та недержавні організаційні структури, які утворені на різних рівнях та реалізують свої рішення через важелі впливу, що належать до їх повноважень, а саме через нормативноправове регулювання, податкову політику, бюджетно-фінансову політику, інформаційно-промоційне забезпечення [7].

Зазначені важелі можуть бути ефективними та сприяти досягненню основної мети механізму у випадку чіткого розподілу повноважень на різних рівнях управління та 3 чітким контролем дотримання норм законодавства i визначених стратегічних цілей. Дослідження дозволяють сформувати структуру механізму управління туристичної галузі в Україні ( табл.1).

Структура управління туристичною галуззю в Україні*

Таблиця 1

\begin{tabular}{|l|l|}
\hline Світовий рівень & $\begin{array}{l}\text { Виконавчі, дорадчі органи міжнародних організацій, що функціонують } \\
\text { в сфері туризму (Всесвітня туристична організація }\end{array}$ \\
\hline Свроінтеграційний рівень & $\begin{array}{l}\text { Виконавчі, дорадчі органи СС, інші організаційні структури, що } \\
\text { функціонують у сфері туризме }\end{array}$ \\
\hline Транскордонний рівень & $\begin{array}{l}\text { Виконавчі, дорадчі органи єврорегіонів, органи, що створюються } 3 \\
\text { метою виконання програм, проектів, дво- і багатосторонніх угод } \\
\text { співробітництва в галузі туризму }\end{array}$ \\
\hline $\begin{array}{l}\text { Загальнодержавний рівень } \\
\text { (державні структури) }\end{array}$ & $\begin{array}{l}\text { Кабінет Міністрів України } \\
\text { Міністерство культури, молоді та спорту } \\
\text { Державне агентство розвитку туризму }\end{array}$ \\
\hline Регіональний рівень та місцевий & $\begin{array}{l}\text { Управління туризму та курортів обласних державних адміністрацій } \\
\text { Управління туризму та курортів районних державних адміністрацій } \\
\text { Управління туризму та курортів міст, селищ, сіл }\end{array}$ \\
\hline Туристичні підприємства & $\begin{array}{l}\text { Туроператори, тур агенції Туристичне бюро екскурсій, туристський } \\
\text { клуб, туристськокраєзнавчий клуб, туристська секція, туристсько- } \\
\text { краєзнавчий гурток, підприємства-комутанти, підприємства - } \\
\text { експлеренти, підприємства - віоленти, підприємства - патієнти. }\end{array}$ \\
\hline
\end{tabular}

*- сформовано на основі $[1,6]$

Великим попитом серед туристів у глобальному економічному просторі користується Канада. Канада - країна, яка пропонує велику різноманітність туристичних послуг, володіє розвинутою структурою міського туризму, культурними об'єктами. Потенціал туристичної галузі схожий до Українського ринку туристичних послуг, тому на прикладі цієї країни розглянемо механізм управління туристичною галуззю.

Канадський туризм завжди буде мати велику підтримку з боку сильного внутрішнього попиту. Найбільшу частку ринку Канади складають безпосередньо канадці, які забезпечують 70\% всіх туристичних витрат. Внутрішній ринок $\epsilon$ найбільш потужним сектором канадського ринку. Міжнародний туризм забезпечують в Канаді туристи із США, Великобританії, Японії, Франції, Німеччини. В Канаді туризм входить до списку зобов'язань міністерства промисловості Канади. Завдяки Канадській Комісії 3 туризму покращується створення динамічної економіки, яка забезпечує велику кількість робочих місць; підтримує великий ріст комерційної діяльності завдяки підвищенню продуктивності праці; забезпечується стабільне економічне, екологічне 
та соціальне майбутнє Канади.

Управління туристичною галуззю Канади здійснюється на трьох рівнях:

1.Федеральний рівень- держава виконує функцію регулятора розвитку туризму шляхом створення федеральних цільових програм та регіональних програм.

2.Регіональний рівень - функціонування територіальних управлінь розвитку туризму.

3.Місцевий рівень - місцеві органи управління розвитком туризму, основною метою їх діяльності $є$ підвищення конкурентоспроможності місцевих підприємств індустрії туризму.

Висновки i перспективи подальших досліджень. Вивчаючи досвід Канади, саме місцевий рівень $€$ потужним інструментом розвитку туризму в Канаді через залучення місцевих підприємств у різноманітні кластери, інформаційно-аналітичну підтримку, нормативно-правову підтримку, податкові пільги тощо.

Отже, вплив міжнародного туризму визначається, як його економічними функціями, а саме, створення доходу, генерування виробничих галузей економіки, стабілізація платіжного балансу так i соціальними через підвищення зайнятості населення , створення додаткових робочих місць. Досвід Канади може бути корисним для України в розвитку туристичної галузі, через формування асоціацій, кластерів, об’єднань, які сприяють розвитку суб'єктів туристичного бізнесу, що входять в їх структуру.

\section{ПЕРЕЛІК ВИКОРИСТАНИХ ДЖЕРЕЛ}

1. Стручок Н.М. Розвиток ринку туристичних послуг в системі економічної безпеки держави : монографія / Н.М. Стручок, І.О.Бочан, Н.Б. Завальницька та ін. - Львів: Вид-во "Сполом", 2013. - 177 с.

2.https://tourlib.net/wto/WTO_highlights_2019.pdf.

3.https://tourlib.net/wto/WTO_highlights_2018.pdf.

4.https://tourlib.net/wto/WTO_highlights_2017.pdf

5.Концепція державної цільової програма розвитку туризму та курортів на період до 2022 р.. / Затв. постановою Кабінету Міністрів України від 5 березня 2014 р. № 71 - режим доступу: https://zakon.rada.gov.ua/laws/show/638-2013-\%D1\%80

6. Управління бізнес-процесами в туризмі : монографія / С.В. Мельниченко, К.А. Шеєнкова. - К. : Київ. нац. торг.- екон. ун-т, 2015. - 264 с.

7.Загальне поняття управління та його види - Режим доступу : http://vuzlib.net/beta3/html/ 1/10954

8. Тотонова Е.Е. Региональный опыт использования туристско-рекреационного потенциала (на примере Канады). Туризм и региональное развитие: сб. науч. ст. Вып. 5. - Смоленск: Универсум, 2008

\section{REFERENCES}

1. Struchok, N.M. (2013). Rozvytok rynku turystychnykh posluh v systemi ekonomichnoi bezpeky derzhavy [Development of the market of tourist services in the system of economic security of the state], L'viv: Vyd-vo «Spolom» [in Ukrainian].

2. International Tourism Highlights (2019). Retrieved from: https://tourlib.net/wto/WTO_highlights_2019.pdf. [in English].

3. International Tourism Highlights (2018). Retrieved from: https://tourlib.net/wto/WTO_highlights_2018.pdf. [in English].

4. International Tourism Highlights (2017). Retrieved from: https://tourlib.net/wto/WTO_highlights_2017.pdf. [in English].

5. Postanova Kabinetu Ministriv Ukrainy «Kontseptsiia derzhavnoi tsilovoi prohramy rozvytku turyzmu ta kurortiv na period do 2022 r.» vid 5 bereznia 2014 r. № 71 [Resolution of the Cabinet of Ministers of Ukraine «The concept of the state target program of development of tourism and resorts for the period till 2022» from March 5, 2014, № 71] (2014). Retrieved from: https://zakon.rada.gov.ua/laws/show/638-2013-\%D1\%80 [in Ukrainian].

6. Melnychenko, S.V. (2015). Upravlinnia biznes-protsesamy v turyzmi: monohrafiia [Management of business processes in tourism]. Kyiv. nats. torh.- ekon. un-t [in Ukrainian].

7. Zahalne poniattia upravlinnia ta yoho vydy [General concept of management and its types]. (n.d.). Retrieved from: http://vuzlib.net/beta3/html/ 1/10954 [in Ukrainian].

8. Totonova, E.E. (2008). Regional'nyy opyt ispol'zovaniya turistsko-rekreatsionnogo potentsiala (na primere Kanady) [Regional experience of using tourism and recreation potential (on the example of Canada)]. Turizm $\mathrm{i}$ regional'noye razvitiye - Tourism and regional development, 5 [in Russian]. 